\title{
X-linked intellectual disability-hypotonic face syndrome
}

INSERM

\section{Source}

INSERM. (1999). Orphanet: an online rare disease and orphan drug data base. $\underline{X-l i n k e d}$ intellectual disability-hypotonic face syndrome. ORPHA:73220

Mental retardation-hypotonic facies covers a group of X-linked syndromes characterized by severe intellectual deficit and facial dysmorphism, with variable other features. 